\title{
GEOGRAPHY LEARNING MEDIA BASED ON CHARACTER EDUCATION IN THE DIGITAL REVOLUTION ERA
}

Ayu Suciani ${ }^{1}$, Desy Irafadillah Effendi ${ }^{2}$, Evi Zulida ${ }^{3}$, Soedirman $Z^{4}$

1Program Studi Pendidikan Geografi, FKIP, Universitas Samudra

2Program Studi Pendidikan Bahasa Indonesia, FKIP, Universitas Samudra

3Program Studi Pendidikan Bahasa Inggris, FKIP, Universitas Samudra

Jl, Prof. Dr. Syarief Thayeb, Meurandeh, Langsa Lama, Kota Langsa, Aceh, 24416, Indonesia

4Program Studi PGSD, Fakultas Keguruan dan Ilmu Pendidikan, Universitas Syiah Kuala

${ }^{4}$ Jl. Teuku Nyak Arief No. 441, Kopelma Darussalam, Banda Aceh, 23111, Indonesia e-mail: eviz.fkip@unsam.ac.id

Received: 17 October 2020, Repaired: 09 August 2021, Approved: 10 August 2021

\begin{abstract}
Abstrak
Dunia sedang menghadapi era revolusi industri 4.0 dimana segala sesuatu serba terkoneksi dengan mesin. Dalam mewujudkan SDM yang siap akan era revolusi industry 4.0, pemerintah melakukan beberapa usaha melalui pendidikan. Karakter merupakan salah satu landasan kemajuan suatu bangsa. Karakter tidak diwariskan secara lahir, namun perlu dipupuk hingga tumbuh menjadi karakter yang diinginkan bangsa. Karakter dapat dibentuk melalui pendidikan sekolah mata pelajaran geografi. Pembelajaran geografi akan memperkenalkan kepada siswa tentang wilayah dimana mereka berada. Dengan demikian, pembelajaran geografi dapat diarahkan untuk mengembangkan karakter religus, nasionalis, mandiri, gotong royong dan integritas yang cinta tanah air. Penelitian ini bertujuan untuk mengetahui karakter siswa dalam pengembangan media pembelajaran berbasis karakter. Penelitian ini dilakukan pada MGMP Geografi SMA di Kota Langsa dan Kabupaten Aceh Timur yang berjumlah sebanyak 27 orang guru. Teknik pengumpulan data adalah wawancara dan mengumpulkan informasi jenis media pembelajaran pada materi geografi di SMA dan karakter yang dibutuhkan dalam mempelajari geografi. Hasil penelitian yaitu (1) Guru memilih sebanyak 83\% materi geografi SMA membutuhkan video sebagai media pembelajaran, video dianggap mampu memberikan penjelasan berupa gambar dengan gerakan serta suara, dengan demikian, video dapat membantu siswa untuk memahami materi geografi; (2) Multimedia interaktif merupakan media yang cocok untuk menumbuhkan karakter mandiri pada siswa. Media ini bersifat interaktif dimana media akan menyajikan materi atau informasi yang sesuai dengan siswa inginkan, oleh karena itu guru harus mampu mengembangkan multimedia interaktif untuk siswanya; (3) Guru memiliki kesulitan yang sama dalam pengembangan media pembelajaran geografi. Kesulitannya yaitu kurangnya keterampilan dalam penggunaan teknologi IT.
\end{abstract}

Kata kunci: Media Pembelajaran, Pendidikan Karakter, Pendidikan Geografi, Revolusi Digital

\begin{abstract}
The world is facing the era of industrial revolution 4.0, where everything is connected to machines. In realizing human resources that are ready for the era of the industrial revolution 4.0, the government makes several efforts through education. Character is one of the cornerstones of the progress of a nation. Character is not inherited from birth but needs to be nurtured to grow into the nation's character. The character can be formed through school education in geography subjects. Learning geography will introduce students to the area where they are located. Thus, geography can develop religious,
\end{abstract}


nationalist, independent, cooperative, and integrity characters who love the homeland. This study aims to determine the character of students in the development of character-based learning media. This research was conducted at the Geography MGMP of SMA in Langsa City and East Aceh Regency, totaling 27 teachers. Data collection techniques are interviews and information on the types of learning media on geography material in high School and the characters needed to study geography. The research results are (1) Teachers choose $83 \%$ of high school geography materials that require video as a learning medium. Videos are considered capable of providing explanations in the form of images with movement and sound. Thus, videos can help students understand geography material; (2) Interactive multimedia is a suitable medium to foster independent character in students. This media is interactive where the media will present material or information according to what students want; therefore, teachers must develop interactive multimedia for their students; (3) Teachers have the same difficulty in developing geography learning media. The difficulty is the lack of skills in the use of IT technology.

Keywords: Learning Media, Character Education, Geography Education, Digital Revolution

\section{INTRODUCTION}

At this time, the world has entered the era of the fourth generation industrial revolution (industrial revolution 4.0), which can be marked by increased connectivity, interaction, and development of digital systems, artificial intelligence, and visuals. The development of the industrial revolution 4.0 uses intelligent engineering and the internet of things as the coffers of movement and connectivity of humans and machines (Government of Indonesia, 2007). Since 2018 Indonesia has entered the era of the industrial revolution 4.0. The government has made various efforts to deal with changes in the 4.0 revolution era.

One of the efforts made is through education. Education is essential to prepare skilled and globally competitive human resources, even becoming one of the national development missions. One of the national development priorities contained in the National Long-Term Development Plan (RPJP) 2005-2025 is the formation of national character through education (Ramdhani, M. A., 2017)

Education is expected to play a role in overall national development beneficial for oneself, society, and the nation. Character is understood as a typical way of thinking and behaving in a person's family, community, nation, and state (Kesuma, D.,
Triatna, C., \& Permana, J., 2013). Character education can develop students' ability to continuously behave well to become God's creatures and trustworthy leaders (Mulyasa, 2013). The moral crisis or lack of character of a society can be seen from the frequent occurrence of social cases such as corruption, acts of violence, porno-action, pornography, drug use, and kidnapping. Therefore, character education is needed by every individual so that social causes can be minimized to create a safe and comfortable environment.

Although the demand for the use of technology continues to increase, students' character must still be prioritized in learning activities. The focal point in KDP policies is religion, nationalism, integrity, independence, and cooperation (Kemendikbud, 2017). Teachers must help students to grow and familiarize their character. Various things can be done to foster the good habits and behavior of students. The thing that the teacher can do is from learning resources.

School is a virtual environment for the implementation of character education. Learning media as a learning resource is one of the keys to character education (Mulyasa, 2013). Geography is one of the subjects in high school that studies the region (region). All phenomena that occur 
in an area can be studied through a geographic approach. Learning geography can introduce. Several studies have been conducted related to character education in geography lessons. The list of studies can be seen in Table 1.

Table 1. List of Character Education Studies in Geography Lessons

\begin{tabular}{cl}
\hline $\begin{array}{c}\text { Title, Author, Year } \\
\text { Published }\end{array}$ & \multicolumn{1}{c}{ Study } \\
\hline $\begin{array}{l}\text { Integrated Character } \\
\text { Education in }\end{array}$ & $\begin{array}{l}\text { The character education } \\
\text { studied is attitude and } \\
\text { beography Learning }\end{array}$
\end{tabular}

\section{Muhsinatun Siasah Masruri}

2010
Development of learning multimedia that includes cognitive, affective, and behavioral aspects and empowering social functions and shaping children's character related to responsibility, intelligence, resilience, and care for the environment.
Research Result

1. The character of the Indonesian nation is the attitude and behavior that refers to Pancasila as the nation's ideology.

2. Geography is a subject at the SMA/MA level that is very appropriate as a forum for the integration of character education. The essence of Geography is the study of nature, humans, and the reciprocal relationship between the two.

3. Character education integrated into geography learning can use various strategies, including Value Clarification Technique (VCT), to clarify values, especially those related to current events.

Multimedia learning geography based on character education is considered feasible and effective to improve student learning outcomes and character.

2013

\begin{tabular}{ll}
\hline $\begin{array}{l}\text { Development of } \\
\text { Character Education- } \\
\text { Based Geography } \\
\text { Learning Tools }\end{array}$ & $\begin{array}{l}\text { Development of geography } \\
\text { learning tools based on } \\
\text { environmental care } \\
\text { character education on the } \\
\text { main subject of the }\end{array}$ \\
$\begin{array}{l}\text { Asymanidar, Dede } \\
\text { Rohmat, Mamat } \\
\text { Ruhimat }\end{array}$ &
\end{tabular}

2013
1. Learning devices based on environmental care character education, the subject matter of the hydrosphere includes components of basic competence, character values of environmental care, standard material (hydrosphere), and environmentalbased learning materials that are adapted to environmental conditions, regions, school vision, and mission, learning activities that lead to the formation of a caring character for the environment and an attitude scale instrument to determine the extent to which students are concerned about the environment;

2. The learning tools (syllabus, lesson plans, and worksheets) developed in this study are effectively used as learning tools in schools to build the environmental care character of students in geography subjects in high school 


\begin{tabular}{ll}
\hline $\begin{array}{l}\text { Character-Based } \\
\text { Geography Education }\end{array}$ & $\begin{array}{l}\text { Character-based geography } \\
\text { education is a learning } \\
\text { design that presents } \\
\text { Learning Vehicle }\end{array}$ \\
content that is oriented not \\
only on the realm of \\
education \\
knowledge and skills but \\
also attitude-oriented.
\end{tabular}

This learning design is seen as effective as a vehicle for population learning. Through a contextual approach,

geography learning is designed with the following themes:

the population as a contextual theme. Learners learn by experience to observe, reason, and present alternative solutions to population problems around their environment. Learning habits like this are an effort to grow students' character who care and are responsible for the continuity of human life on Earth and learn to live in harmony with their environment.

\begin{tabular}{|c|c|}
\hline $\begin{array}{l}\text { Integrating the Values } \\
\text { of Local Wisdom of } \\
\text { the Karampuang } \\
\text { Indigenous Peoples in } \\
\text { Character Education } \\
\text { Oriented Geography } \\
\text { Learning in High } \\
\text { Schools }\end{array}$ & $\begin{array}{l}\text { 1. Analyze the values of } \\
\text { local wisdom of the } \\
\text { Karampuan indigenous } \\
\text { people } \\
\text { 2. and integrate local } \\
\text { wisdom in geography } \\
\text { learning. The approach } \\
\text { used in this research is } \\
\text { a qualitative case study. }\end{array}$ \\
\hline
\end{tabular}

\section{Erman Syarif}

2019

1. The local wisdom values of the Karampuang indigenous people are religion, care for the environment, love the homeland, hard work, honesty, friendship, social care, responsibility, and friendship.

2. Integrating the values of local wisdom of the Karampuang indigenous people in geography learning in class XI on essential competencies 3.6 Analyzing local wisdom in agriculture, mining, industry, and tourism, especially in using natural resources. Integrating local wisdom values is expected to create an education system with quality and human character resources.

Table 1 there are five studies on character education in geography education. Among the five studies, there is only one study that examines geographybased learning media for character education. The results showed that multimedia learning geography based on character education was considered feasible and effective to improve student learning outcomes and character. However, no study on geography learning media has been based on five religious characters, nationalism, integrity, independence, and cooperation.

This research can reference the characters needed in studying geography and be the initial basis for teachers developing character-based learning media. In other words, teachers can develop learning media that can help students develop the characters needed in learning geography.

\section{RESEARCH METHODS}

The research location was conducted in Kota Langsa and Kabupaten Aceh Timur. Kota Langsa is located at $04^{\circ}$ $24^{\prime} 35.68^{\prime \prime}-04^{\circ} 33^{\prime} 47.03^{\prime \prime} \mathrm{LU}$ and $97^{\circ} 53^{\prime}$ $14.59^{\prime \prime}-98^{\circ} 04^{\prime} 42.16^{\prime \prime}$ BT while Kabupaten Aceh Timur is located at $4^{\circ} 09^{\prime} 21.08^{\prime \prime}-5^{\circ}$ 06' 02.16" LU and 97 15' 22.07" - 97 $37^{\circ}$ 47.22" BT. The location map can be seen in Figure 1.

The population of this study was all 27 people of the Geography MGMP of Langsa City and East Aceh High School. Data collection techniques are interviews. The information collected is information on the type of learning media on geography material in high school and the characters needed in studying geography. 


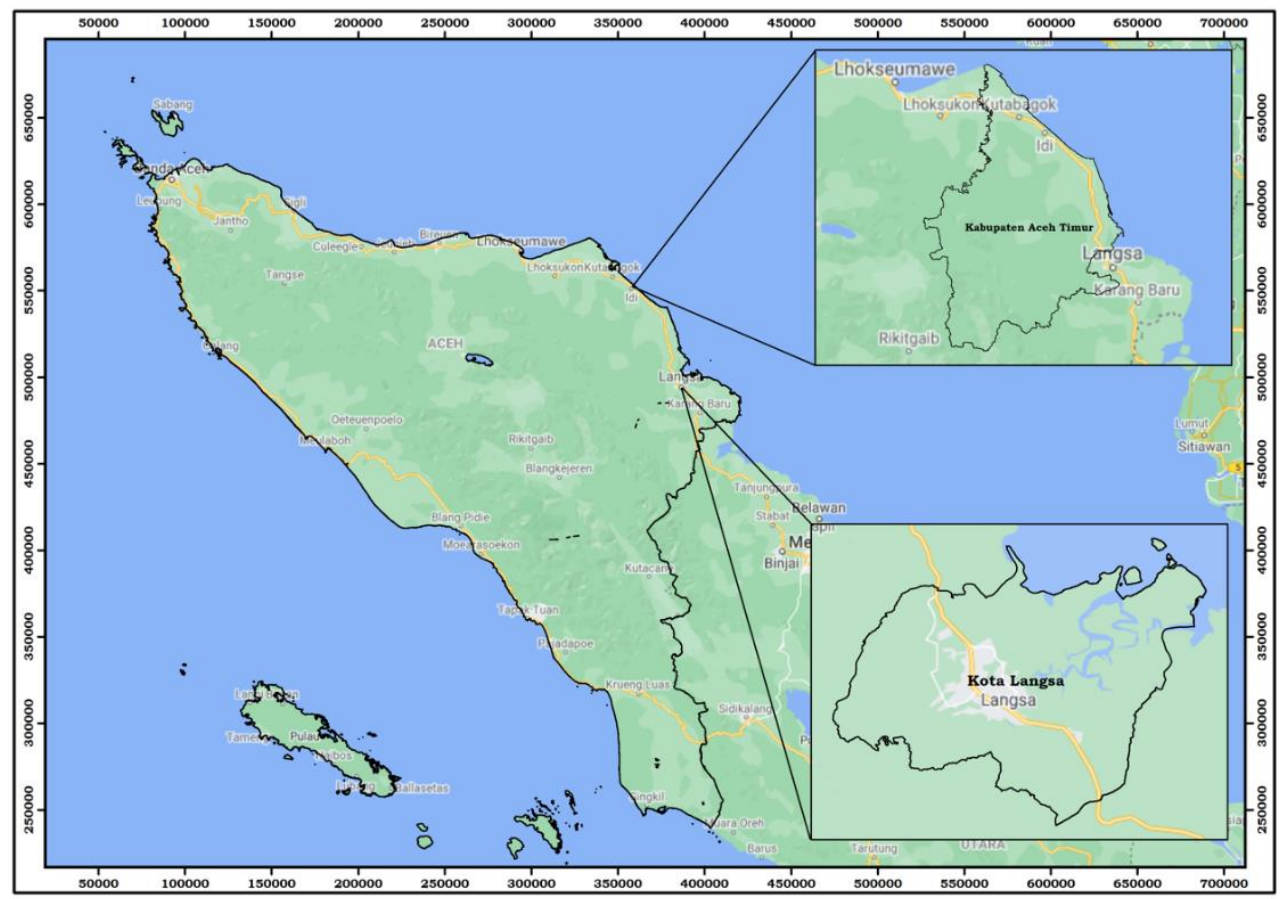

Figure 1. Research locations in Langsa City and East Aceh District

\section{RESULTS AND DISCUSSION Media Types of Geography Learning}

In this study, there were seven types of geography learning media, including video, images, audio, audiovisual, teaching aids, interactive multimedia, and direct learning in the field. At the same time, the geography learning materials for the SMA level are 18 materials. Therefore, the teacher chooses from seven types of learning media based on the needs of high school geography material. The results of the election can be seen in Figure 1.

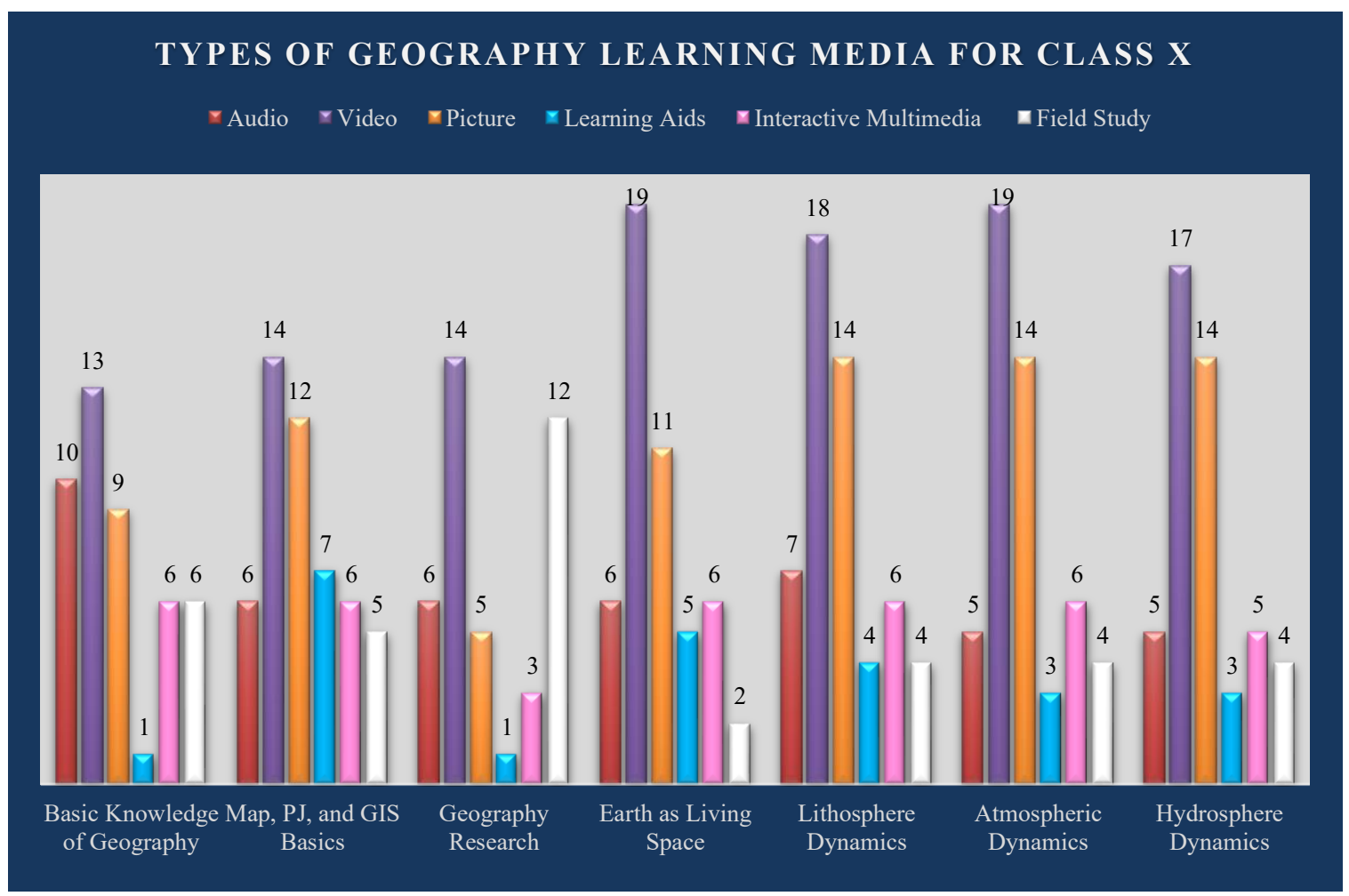

Figure 2. Types of Classroom Geography Learning Media X 
Based on Figure 2, class $X$ has six geography learning materials. In all class $X$ materials, the need for the same type of learning media is in the first order, namely video, and in the fourth-order, namely interactive multimedia. Furthermore, four of the six materials require pictures as the

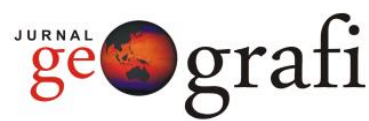

second-order learning media except for the basic knowledge of geography, which requires audio media in the second place before image media. Geography research materials require learning media through direct learning in the field after video media.

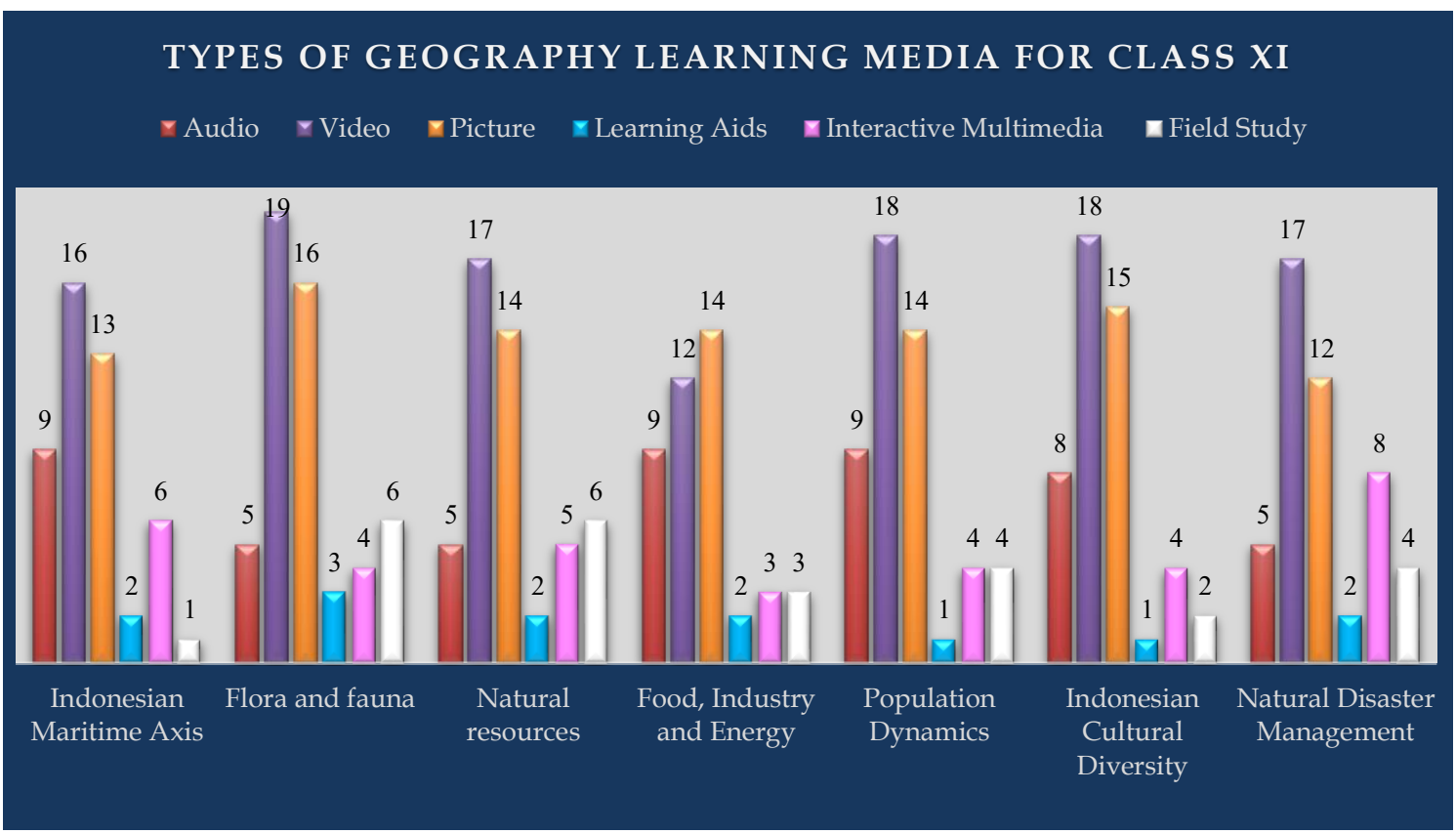

Figure 3. Types of Geography Learning Media Class XI

In Figure 3, class XI has seven geography learning materials. Six of the seven materials require video as the first order and pictures as learning media, while learning media in food, industry, and energy is the opposite. While the props are in the last order except for the maritime axis material, Indonesia is in fifth place before studying directly in the field.

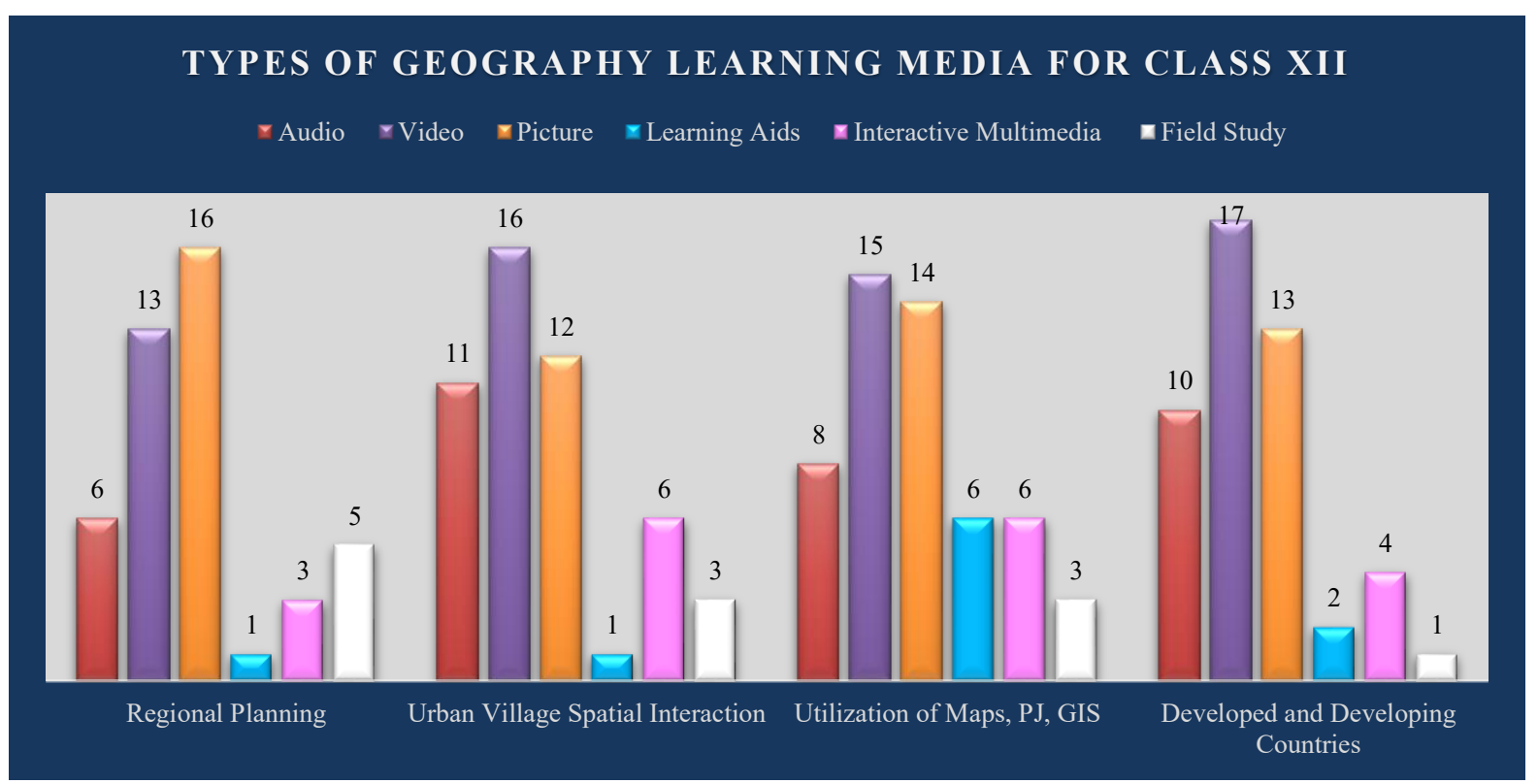

Figure 4. Types of Class XII Geography Learning Media 
In Figure 4, class XII has four geography learning materials. Three of the four materials require the same order in the first to fourth media: video, images, audio, and interactive multimedia. At the same time, the material for regional planning requires media with a sequence of images, videos, audio, learning in the field, interactive multimedia, and teaching aids.

Delivering high school geography material always requires learning media. Video and image media are the most needed media in all geography learning materials. The need for videos and pictures in all geography learning materials is based on concrete geography material. Although concrete material is tangible and can be seen, such as lithospheric dynamics material, which discusses volcanoes that have a confirmed form, students will not understand volcanoes only through verbal explanations. Therefore, it must be shown directly visually through pictures, videos, and straight to the field.

Interactive multimedia is also needed for all materials but does not rank first, even though interactive multimedia can present images, audio, and video attractive. In addition, the advantages of interactive multimedia are that it can make students learn on their own because there are explanations, examples, and practice questions. This is caused by the system of providing media by teachers more often downloads from the internet and is combined with homemade ones. This is often done because it is considered more practical and efficient. The most often downloaded media are videos and images and materials in the form of ready-to-use power points. While interactive multimedia is not widely presented on the internet, there are still not many interactive multimedia developers for geography material.
Therefore, teachers must be able to make their learning media according to the needs and character of their students.

The teacher found several difficulties in developing learning media that matched the needs of geography material. A common difficulty found was the availability of materials and tools in schools. Even though the teacher has prepared the media in PowerPoint, the unavailability of a projector in each class causes the teacher not to use the media. Especially on map material, PJ and GIS require teaching aids and direct practice, which requires materials and tools provided directly by the school so that learning objectives are achieved. As a result, the teacher only explains the material verbally with examples of familiar phenomena.

Another difficulty is that there is a lack of expertise in the use of IT-based media. Meanwhile, in the era of the digital revolution, learning media cannot be separated from technology. In addition, the use of technology as a learning medium will significantly assist teachers and students in learning geography. The limited ability of teachers in developing IT-based media is due to the very lack of facilities in schools and the lack of competency training for teachers. Although there is no special technology training for teachers, teachers can develop themselves self-taught through online training. Self-development independently requires a solid and stable internet signal, but it is not found in the area where they live and even at school.

\section{Expected Student Characters in Geography Materials}

The results showed that all high school geography materials required five characters. The order of character requirements needed can be seen in Figure 4 . 


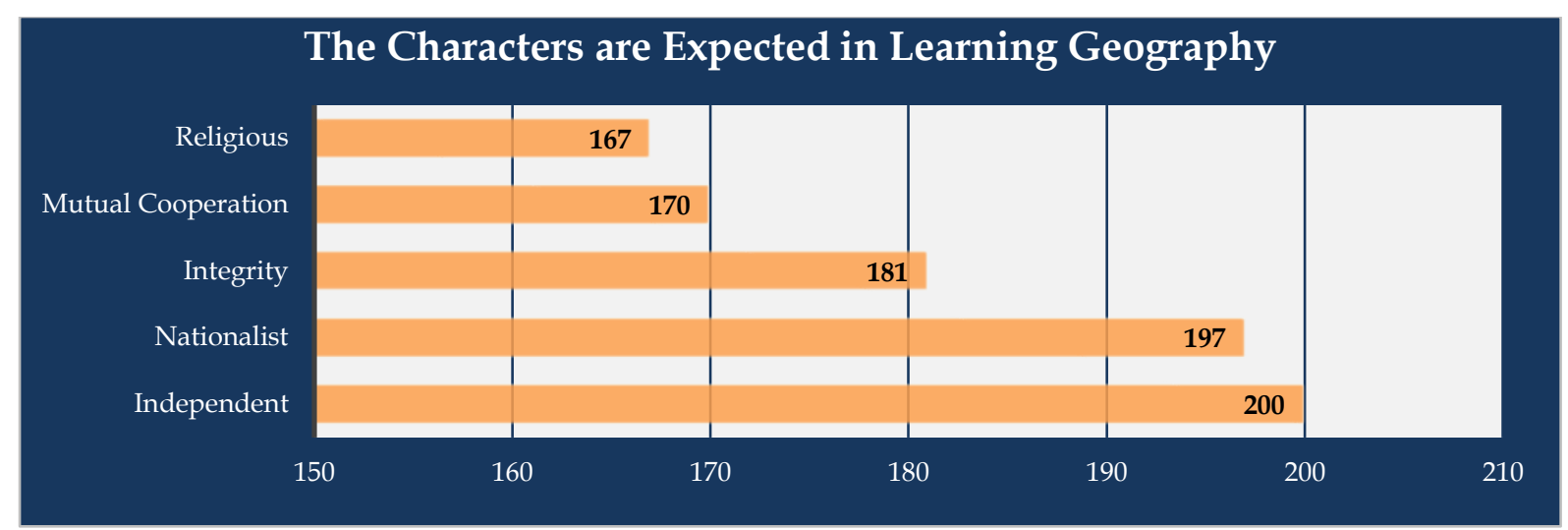

Figure 4. The Characters are Expected in Learning Geography

Based on Figure 4 . the sequence of characters starting from the most dominant in geography learning is independent, nationalist, integrity, cooperation, and religious character. Independent character is the first order that must be possessed in every high school geography material. The teacher hopes that students can learn from various sources without depending on others and have high fighting power to realize their goals.

In learning geography, the surrounding environment can be a source of learning. With an independent character, students will always see the phenomena around them as a source of learning. Furthermore, students will begin to find out from various references so that they are expected to build other characters. However, teachers still have to help students to build these characters incredibly independent characters.

\section{Learning Media of Geography based on Character Education}

The type of geography learning media that is most needed in each material is video. The reason, because the video is widely available on the internet. While the main character needed in learning geography is independent. To grow independent characters, teachers are not enough to use videos as explanations. Instead, teachers must create learning media that suits the needs of students.

Various types of media can be combined into one, namely through interactive multimedia. Interactive multimedia can be used by teachers in the classroom and students wherever they are. In addition, teachers can provide examples through phenomena from students' areas to foster nationalism, integrity, cooperation, and religious character. Therefore, teachers must be able to create interactive multimedia for their students. Thus, teachers can help students to be able to grow independent characters by continuously monitoring the use of interactive multimedia by students.

\section{CONCLUSION}

1. Characters in geography learning start with the most dominant being independent, nationalist, integrity, cooperation, and religious. The teacher expects the independent character in geography learning so that students always want to learn starting from themselves and keep learning anytime and anywhere.

2. Learning media needed in geography learning materials include class $\mathrm{X}$ basic knowledge of geography, map, PJ, and GIS basics, geography research, Earth as living space, lithosphere dynamics, atmospheric dynamics, and hydrosphere dynamics. Class XI materials include the Indonesian maritime axis, flora and fauna, natural resources, food, industry, energy, population dynamics, Indonesian cultural diversity, natural disaster management. Class XII materials include Regional Planning, urban village spatial interaction, utilization of maps, PJ, GIS, and developed and developing countries. 


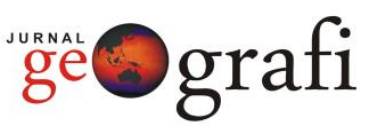

3. Teachers choose $83 \%$ of high school geography materials that require video as a medium of learning. Video is considered capable of explaining the form of images with motion and sound. Thus, videos can help students to understand geography material.

4. Teachers should help students to develop good character. Interactive multimedia is a suitable medium to foster independent character in students. This media is interactive where the media will present material or information following what students want. Therefore, teachers must be able to develop interactive multimedia for their students.

5. Teachers have the same difficulty in developing geography learning media. Again, the difficulty is the lack of skills in the use of IT technology. However, teachers still realize that IT skills are needed in every geography material. As a result, the use of attractive media and following the era of the digital revolution cannot be achieved optimally.

Suggestions for teachers to continue learning to develop themselves in developing technology-based learning media through training or self-taught. In addition, it is hoped that support from the education office will routinely organize training related to learning technology for teachers. Finally, it is also hoped that the direct support from the government is to fulfill the technological facilities needed by teachers and students to create a technologyliterate society.

\section{REFERENCES LIST}

Arsyad, Azhar. (2010). Media Pembelajaran. Raja Grafindo Persada. Jakarta.

Dale, E. (1969) Audiovisual Methods in Teaching. New York. Holt, Rinehart and Winston Inc. The Dryden Press.

Gunawan, H. (2012). Pendidikan Karakter Konsep dan Implementasi. Alfabeta. Bandung.

Kementerian Pendidikan dan Kebudayaan Republik Indonesia. (2017). Konsep dan Pedoman: Penguatan Pendidikan Karakter.
Available at http://jurnal.unimed.ac.id/2012/index.php/geo e-ISSN: 2549-7057 | p-ISSN: 2085-8167

Kementerian Pendidikan Nasional. Jakarta

Kesuma, D., Triatna, C., \& Permana, J. (2013). Pendidikan Karakter: Kajian Teori dan Praktik di Sekolah. Remaja Rosdakarya. Bandung.

Lestari, A. P. (2015). Bahan Ajar Kearifan Lokal pada Mata Pelajaran Geografi Sebagai Pendidikan Karakter.

Masruri, M. S. (2010). Pendidikan Karakter yang Terintegrasi dalam Pembelajaran Geografi. Informasi, 36(2).

Mulyasa. (2013). Manajemen Pendidikan Karakter. Bandung. Bumi Aksara.

Ningrum, M. V. R., Iksan, M., \& Sugiarto, B. (2013). Pengembangan Multimedia Pembelajaran Geografi Berbasis Pendidikan Karakter. Geo Edukasi, 2(1).

RI (Republik Indonesia). (2007). UndangUndang No. 17 Tahun 2007 Tentang Rencana Pembangunan Jangka Panjang Nasional Tahun 2005 - 2025. Lembaran Negara RI Tahun 2007. Sekretariat Negara. Jakarta.

Ramdhani, M. A. (2017). Lingkungan pendidikan dalam implementasi pendidikan karakter. Jurnal Pendidikan UNIGA, 8(1), 28-37.

Rifai, M. H. (2017). Pemilihan Media dalam Pembelajaran Geografi. Edudikara: Jurnal Pendidikan dan Pembelajaran, 2(2), 125136.

Setiawan, I. (2006). Peningkatan Kualitas Pembelajaran Geografi Melalui Pengembangan Media Pendidikan. Jurnal Geografi Gea, 6(2).

Sidauruk, T. (2013). Pendidikan Geografi Berbasis Karakter Sebagai Wahana Pembelajaran Kependudukan. JUPIIS: Jurnal Pendidikan Ilmu-Ilmu Sosial, 5(2).

Sugandi, D. (2015). Pembelajaran Geografi sebagai Salah Satu Dasar Pembentukan Karakter Bangsa. Sosiohumanika, 8(2).

Syarif, E. (2019). Integration of Local Wisdom Values of Indigenous Peoples of Karampuang in Learning GeographyOriented Character Education in High Schools. La Geografia, 17(2), 31-39.

Khan, Y. (2010). Pendidikan Karakter Berbasis Potensi Diri. Pelangi Publishing. Yogyakarta. 
Available at http://jurnal.unimed.ac.id/2012/index.php/geo e-ISSN: 2549-7057 | p-ISSN: 2085-8167

Miftah, Z. (2011). Implementasi Pendidikan Karakter Melalui Bimbingan dan geografi

Konseling. Gema Pratama Pustaka. Surabaya. 